\title{
Effects of Cheating on Accurate Assessment
}

\author{
Deepika Nelson, Julia Devardhi and Abdulaziz Dino
}

School of Foreign Language Studies, Main Campus, Post Box No: 53, Haramaya University, Ethiopia

\begin{tabular}{|c|c|}
\hline Abstract & Article Information \\
\hline \multirow{2}{*}{$\begin{array}{l}\text { In the view of Boud and Falchikov (2006) assessment has the clear purpose of } \\
\text { certifying a level of attainment of a student at the point of completion of a course } \\
\text { or a program. To produce sufficient number of ethical citizens, advancement of the } \\
\text { quality of student performance assessment has been irrefutably recognized. } \\
\text { Student performance assessment is a procedure to confirm institutional efficiency. } \\
\text { Student assessments are widely accepted as an important part of the learning } \\
\text { process. Thus, the primary purpose of this study is to scrutinize the impacts of } \\
\text { exam administration and student-paper scoring approaches on accurate } \\
\text { performance assessment, taking the case of one of the Universities in Ethiopia } \\
\text { and the world in general. }\end{array}$} & $\begin{array}{l}\text { Article History: } \\
\text { Received }: 23-07-2012 \\
\text { Revised }: 15-09-2012 \\
\text { Accepted }: 20-09-2012\end{array}$ \\
\hline & $\begin{array}{l}\text { Keywords: } \\
\text { Assessment } \\
\text { Performance } \\
\text { Education } \\
\text { *Corresponding Author: } \\
\text { Deepika Nelson } \\
\text { E-mail: } \\
\text { dr.deepikanelson@gmail.com }\end{array}$ \\
\hline
\end{tabular}

\section{INTRODUCTION}

An academic revolution has taken place in higher education in the past half century marked by transformations unprecedented in scope and diversity. With the intention to enhance the longtime complained quality of higher learning in Ethiopia, the conception of practicality has been highly valued by the Ethiopian Higher Educational Institutions (HEls). However, there are observations that the value given, particularly to, practicality of student assessment has not been adequately supported by compatible actions. Noticeably, the majority of course examinations in Ethiopian HEls focus on classroom invigilation in form of either a mid-term or final exam, therefore, upgrading the quality of invigilation becomes the crucial need of the hour. The issues of concentration and impartiality have also developed into prominent subjects pertaining to student paper scoring. Instructors might be accustomed to different ways of paper scoring. By any means, the practice should secure fair judgment of students whereby they are accurately represented by what they have written on paper.

Instructors lack well-structured awareness concerning fair and balanced paper scoring. So the only ways instructors might learn is either through reading, inquiring, or their personal understanding which is commonly subject to extreme variation among papers. The lack of consistent psychological and mental condition on the instructors' side is then believed to lead to unfair and unequal judgment of student performance. Basically, exam administration is mainly about securing contexts for independent assessment. This would require planning to select favorable rooms or sites, favorable sitting arrangements, regimented settings, as well as favorable times. Nitko and Brookhart (2007) emphasize examinees should be aware of the assessment procedures beforehand. Inconveniences in one or all of these contexts would limit students not to exert their maximum real potential on exams.

In the absence of firm control in invigilation the students who perform well are basically the ones who suffer irrespective of all the preparation, being regular to the class, working on class assignments and seeking the possible higher concentration on exams. In fact, students could inform invigilators that they are not wellfunctioning due to others' interruption in search of copying. But this would result in further frustrations denying concentration on the students' side. Some clever students lack focus 


\section{Deepika Nelson, Julia Devardhi and Abdulaziz}

even when they tend to refuse to give answers, leave alone reporting the case immediately to invigilators. Therefore, invigilators emerge as the only group who could immediately secure the psychosocial and academic welfare of all students.

Ethiopia is embarked on a higher education expansion and reform program of impressive dimensions. Its Education Sector Development Program II (2002) sets out a vision for education, higher education's role within this and aims: 'The overall strategy is to provide good quality higher education in larger numbers, with diminishing dependence on public resources in the longer term'. Thus, in its main aim the reform program links the issues of quality, the context of expansion and greater market awareness.

In 2003 the Ethiopian Government introduced a higher education proclamation (Federal Republic of Ethiopia, 2003), establishing wide ranging reforms to the higher education system and setting up key agencies to guide and oversee the sector, including the Ethiopian Higher Education Strategy Institute and the Quality and Relevance Assurance Agency (QRAA).

Ethiopia's QRAA might be better to think in terms of development of a national framework and guidelines as the starting point. Institutions can ensure that programs of study meet minimum standards through a variety of internal mechanisms that include checks against benchmarks, validation and review checklists and so on. In the case of research, proposals may be checked, for instance to ensure compliance with ethical standards. In many developed countries, there are also checks at national level to ensure acceptable standards.

Processes to measure standards are the cornerstone of higher education quality systems throughout the world. In most systems such processes are considered essential (though some would consider them insufficient) to ensure the quality of education and educational services provided by higher education institutions. Harvey (1995) suggests that standards may be expressed in various ways: academic standards (for example, students fulfilling the requirements of the course); standards of competence (such as the achievement of key skills); and service standards (for example, student charters). It could be argued that standards (academic, competence, service, and so on) can only be defined within the context of an institution's mission. Thus, a university college with a specific mission and niche market might wish to set
Sci. Technol. Arts Res. J., July-Sep 2012, 1(3): 68-74

different standards of competence from a research-focused university: for example stressing practical skills rather than theoretical knowledge. Thus, the concept of setting national standards is, at least, debatable.

Candidates and other persons who are directly implicated in an irregularity affecting the validity of examination scores are usually subject to sanctions including: the exclusion from examinations, withholding or non-reporting of results and even decertification (ABEM, 2004; Linn, Baker and Dunbar, 1991).

\section{Invigilators Protecting Independent Exam and Higher Concentration}

Invigilators, therefore, take the major share of the responsibility and the influence to secure students' independent examination and maximum concentration. Independent examination happens when students are capable of executing only by themselves by using the opportunities and resources equally shared by all counterparts. And exam concentration is achieved only when students are prevented from inconvenient settings such as poor sitting arrangement, too much emphasis on paper qualification and non completion of syllabuses, etc.

A combination of suggestions are thus forwarded by instructors of the higher education institutions on how to secure independent exam and utmost concentration to all students: clear exam instructions, close follow ups, easily manageable seating arrangements, invigilator vigilance, orientations, and decreasing number of students. Some suggest assigning as many invigilators as possible; while a graduate assistant (GA) recommends "serious measures both on students and invigilators". In this regard, as to take appropriate measures, both Department Academic Council (commonly known as DC) and Faculty Academic Commissions (commonly known as AC) have set of legal authorities and duties stated in the senate legislation: One of the powers and duties of the academic commission is that it ..."Shall settle any academic problems which concern the faculty (HU senate legislation, 1997)." Similar rules and regulations are also followed in other higher education institutions nationally as wells as internationally.

The department academic council shall have the powers and duties to... "Settle or propose to the academic commission ways and means of solving any academic problems which concern the department (HU senate legislation, 1997)." 


\section{Deepika Nelson, Julia Devardhi and Abdulaziz}

Side talks and/or facial contacts plainly have effect on efforts of student assessment. And, it can be controlled by telling students to develop high-quality academic ethics, by easily manageable seating arrangement, and through tough control and the possible wider spaces to students. This shows that students might be discouraged by their own unpreparedness.

If students are affected by the cold, hot or windy moments, the invigilator can take immediate actions by opening or closing windows and/or doors, and by allowing students optional seats, etc. Invigilators should also assure that students are not copying from other materials, or from each other. Exam papers should also be distributed equally fast as possible. Hence, biases can be avoided both by strict controlling, equal treatment and balanced exam-start, and exam-end.

\section{Effects of Cheating on Accurate Assessment}

"The more any quantitative social indicator is used for social decision-making, the more subject it will be to corruption pressures and the more apt it will be to distort and corrupt the social processes it is intended to monitor. . . When test scores become the goal of the teaching process, they both lose their value as indicators of educational status and distort the educational process in undesirable ways." (Campbell's Law, 1976)

Academic cheating is of increasing concern in international higher education. One common form of academic cheating is plagiarism, which some local higher education institutions have confronted through training and employing detection software. However, in reality, academic cheating is a complex construct that extends far beyond plagiarism to include a wide range of student beliefs, attitudes, and practices that act to corrupt recorded achievement scores.

Cizek (2004) has provided an expanded definition of academic cheating that covers the complexity of the behavior along with the measurement implications. This definition highlights the intentional nature of the action, the possible motive behind the act, as well as the impact on validity and fairness. He defined academic cheating as:

. . . any intentional action or behavior that violates the established rules governing the administration of a test or the completion of an assignment, gives one student an unfair advantage over other students on a test or an assignment, or decreases the accuracy
Sci. Technol. Arts Res. J., July-Sep 2012, 1(3): 68-74

of the intended inferences arising from a student's performance on a test or an assignment.

In illustrating overall features of academic fraudulence, one of the Universities' Student Code of Conduct defines the practice of cheating inclusively:

Cheating is the use of inappropriate and acknowledged materials, information or study aid in any academic exercise. More specifically, in academics, cheating is defined as deceiving or misrepresenting in a manner that creates a false impression of student performance in a class. Cheating includes, but is not limited to, copying another's work in a whole or in part, passing off another's work as one's own, plagiarism, fostering cheating, conspiring to cheat, or other tricks and devices which create a misinformation about a student's performance, including other academically dishonest conducts which are described below. A teacher may reasonably conclude that a student is cheating if, during an exam, the student is seen looking at another student's paper.

Examination malpractice has lead to fallen education standards in almost all the universities in Ethiopia. A simple survey of several universities in the country reveals that students engage in examination malpractices and cheating of some kind in all institutions employing various tactics such as:

- Students cheat in the examinations through: importing pre-prepared notes in 'cassettes', notes written on the body, on the clothes into the examination rooms.

- Copying from one another between students who arrange before to sit next to each other.

- The use of SMS from cell phones and programmed calculators.

- Plagiarism.

- Dishonesty (Moving to copy work in the toilets, or writing notes or information on the desk or table that one regularly uses).

- Examination misconduct.

- Handling of Missing marks, missing marks, wrongly recorded marks, lost marks and non existent marks.

- Impersonation: especially hiring someone else to do examination (re-take examinations). Who are doing the examinations and the writing of dissertations?

- Poor Examination marking and logistics. 
Deepika Nelson, Julia Devardhi and Abdulaziz

- External assistance given to candidates by invigilators.

- Prior knowledge of the examinations questions through leakage.

- Substitution of answer scripts/booklets at a later time at a fee by internal examiners.

- Bargaining for better marks from a lecturer at a fee.

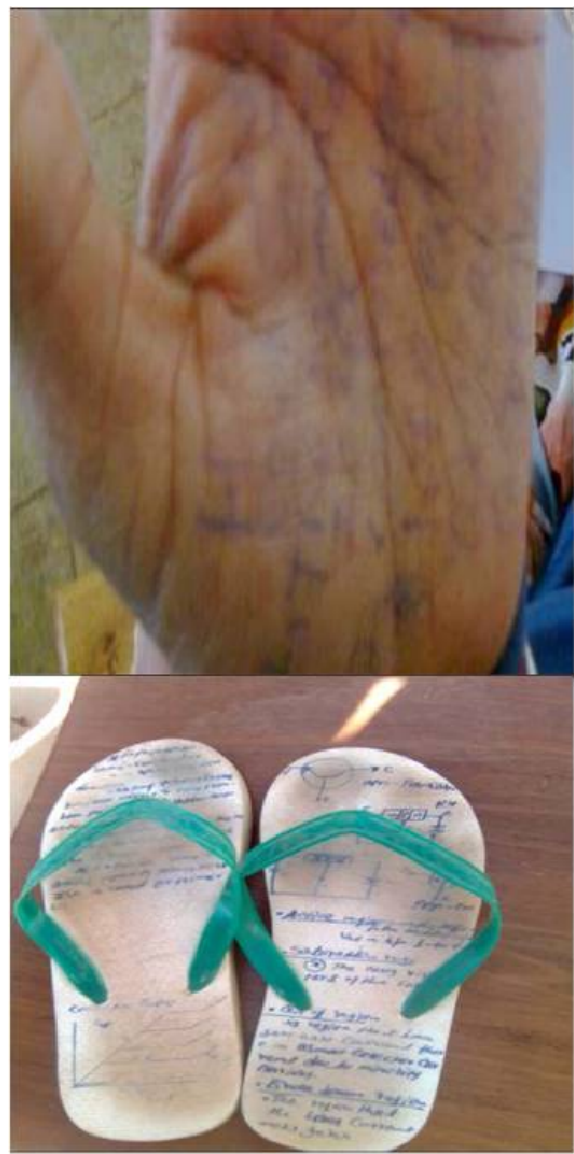

Figure 1: Ways of Malpractice.

Cheating has integrated effects to students. First of all, students develop a culture of dependence that results in a very artificial learning. When repeated, students get addicted; which would deny them a chance to test out their natural potential. To its utmost level, they attempt to try risky techniques. It has been repeatedly observed that some students come with unique ways of cheating.

Sometimes there are cases that clever students knowingly allow others to see their papers. By this, they share the troubles as active producers, if not active consumers. This act is termed by the students' code of conduct as 'fostering cheating'; while 'plagiarism' inclines to the denial of deserving credit in the use of other's works: Fostering cheating: A student who intentionally allows his/her paper to be copied is
Sci. Technol. Arts Res. J., July-Sep 2012, 1(3): 68-74

cheating as much as the student doing the copying. Such individuals shall be sanctioned the same punishment as the person doing the copying. Students are responsible for the security of their own papers.

Exams almost become group works; many students plan to execute in group. Some students get encouraged to copy when they are not prepared due to illness or other related troubles; but not all students. And, even top scorers may fail due to others' group work advantages. Although all students are highly affected by the exam-room mismanagement, clever students are suggested as ones who share the majority of the harm. Relatively, they are the ones who value careful learning, preparation, exam discipline, maximum concentration and maximum possible results. Yet a lecturer states that all students equally share the harm; he underlines "because injustice benefits nobody". While students fail to develop interest in the course, it affects all other determinant factors. This results in inadequate or no preparation, and then disruptive exam-room behaviors. Others who might have the interest but are not patient in learning or preparing would also plan to copy. Language incomprehension, by itself, remains another motivating factor for exam misbehavior. Indisputably therefore, invigilation affects students as much as course understating, preparation, interest and language. Therefore Cheating may be considered somewhat of a cognitive shortcut precluding the use of complex self-regulatory strategies often favoured in mature learners. From a developmental perspective, cheating will likely occur in various quantities dependent on individual and contextual factors.

\section{Paper Scoring as Fundamental Constituent of Assessment}

When assessing student writing, there are often legitimate reasons for seeking both a holistic score as well as a set of analytic scores. Holistic scoring refers to assessments in which a single summary judgment of quality is rendered, albeit often guided by a conceptual framework that articulates essential dimensions upon which quality is to be defined (Huot, 1988). In analytic scoring, writing is described in terms of essential attributes and individual judgments recorded for several constituent attributes. Holistic scoring is thought by some to enable a more complete and appropriate depiction of a phenomenon as complex as writing, which they feel can never be adequately deconstructed into several parts. Moreover, singular summary judgments may fulfill certain assessment purposes perfectly well, while being quicker and, therefore, more economical 


\section{Deepika Nelson, Julia Devardhi and Abdulaziz}

(Spandel and Stiggens, 1980). Analytic scoring, on the other hand, may be considered more informative and therefore potentially relevant to instructional and programmatic decision making, though it is more time consuming and therefore generally more expensive to conduct (Cooper and Odell, 1977).

There is shortage of education or training exclusively pointing to paper scoring. Despite its criticality in student performance assessment, institutions fail to adopt baseline rules and regulations in a form of orientations, at least. What instructors follow is commonly their own common sense, or otherwise their conversations with colleagues.

Increasingly, there is much subjectivity in the preference of scoring settings; the time, place and way of actual scoring. While some instructors have no particular preference in all or some of these settings, others set favorable settings which they believe is conducive to them. Some instructors have a habit of scoring papers soon after the exam is administered. Others may prefer days or weeks after. But the majority says they are controlled by grade submission deadlines. This means, they do not start scoring unless there is deadline pressure. The point here is the sooner the instructors' score their papers, the more they exert multi-directional and in-depth judgment of students' performance. Or, if there are inconveniences, students will have the chance to see their exam-papers soon. Contrary to expectations, there might be cases of deliberate delays on the instructors' side mainly due to fear of student reactions. Delayed starts always have non-inspirational effect on the instructors; or at least they tend to do it in a hurry against concentration. This is also against the views of Nitko and Brookhart (2007). "When you score student responses to an assessment, you have a responsibility to evaluate the responses accurately and to report the results to students in a timely manner".

\section{Towards an Improved Assessment and Examination System}

Examination is the pivotal point around which the whole system of education revolves and the success or failure of the system of examination is indeed an indicator of the success or failure of that particular system of education. It would be pertinent to examine the present system of examination with a view to determine as to whether it actually serves the purposes it purports to serve. The two basic assumptions of any examination worth the name are that (a) it should be valid and (b) it should be reliable. The two are distinct
Sci. Technol. Arts Res. J., July-Sep 2012, 1(3): 68-74

concepts. An examination is said to be valid if it performs the functions which it is designed to perform .The concept of reliability, of course, refers to consistency of measurement. In actual fact, the prevailing system of examination and its mode of conduct defy both these assumptions. The system has degenerated to an extent that its validity and reliability are questionable. Examination is no longer regarded as a test for evaluating the performance or judging the scholastic attainment of students. The reason being that there is a complete breakdown of the whole system of examination, almost all over the country, and at all levels of education. The system of examination needs review and reformation. We are, however, not the appropriate forum to delve into the issue of evaluating the system of examination, with a view to identify its drawbacks and suggest remedial measures. This is not an area of concern for the Commission. We are, however, concerned, and are indeed alarmed, by the rising crescendo of continuing corruption and malpractices in examinations. We should, therefore, review the current legislation and by-laws of the concerned institutions to find out as to why such laws have failed to cope with the situation, and suggest accordingly remedial measures.

The use of unfair means in examination has assumed a proportion of an epidemic and needs to be tackled on a war-footing basis. Barring a few institutions, elsewhere in the country, the educational establishments are experiencing an ever increasing trend towards the use of unfair means in examinations. Such establishments are unable to stop this drive.

The educational institutions have quite elaborate rules/ regulations which provide for appropriate penalties to deal with malpractices in examinations. The penalties range from cancellation of all the papers in the examination, and in more serious cases, disqualification of the candidate from appearing in examination for certain terms/years.

University lecturers require training and/or updating on examination and assessment practices including on how to choose appropriate assessment methods, set, administer, mark and communicate examinations results. The malpractices in examinations have mainly contributed to the overall deterioration of the standard of education in the country. We need to carefully align assessment methods with intended outcomes that students are to learn with appropriate performance indicators. This requires the generation and use of suitable performance 
Deepika Nelson, Julia Devardhi and Abdulaziz

indicators, then observing and recording student performance.

\section{Curbing the Menace (Remedial Measures)}

The actualization of the goals of education will continue to be a mirage if the scourge of examination malpractice is not eradicated from the system. The country will end up producing graduates who lack the knowledge, skill and competence to exploit the resources of the nation. Thus it is incumbent to highlight the importance of integrity of the examination system by conducting a public awareness campaign. To be able to curb examination malpractices, there should be continuous grassroots campaigns and seminars organized by all related with the education sector on the dangers associated with examination malpractices. These seminars and campaigns will help restore the lost cherished moral values of honesty, hard work, dedication and uprightness that hitherto characterized the society. Objective evaluation procedure can be adopted which is related with the final out-put and directly impacts malpractice in examination. Finally, workshops can be conducted for invigilators to make them aware of the use of technology in cheating. The increase in technological devices has made cheating more sophisticated. For example, a lot of academic information can be stored in handsets for direct use in examination halls or for onward transfer via SMS to other students anywhere in the country. Hence, prevention of examination malpractices and irregularities would be better than trying to cure them.

\section{CONCLUSION}

The root cause of malpractices in examinations can be attributed to decreasing quality in preparation that is directly and indirectly related to the deterioration in the quality of teaching and learning in our schools. Further, there is gross inadequacy of qualified and motivated teachers who would be ready to go the extra mile to mitigate the problem of cheating in examinations. Hence, Ethiopian higher education institutions have a responsibility to establish mechanisms that encourage change in teaching and learning. Everyone who participates in the development or implementation of examination and assessment systems has a responsibility in ensuring that it adheres to the requirements of validity, reliability and fairness.

Biggs (2003), for example, talked about the need for the constructive alignment of both teaching and assessment with curriculum objectives. Increasingly, then, in repairing and
Sci. Technol. Arts Res. J., July-Sep 2012, 1(3): 68-74

improving assessment practices within institutions the focus has rightly been on the overall assessment scheme, inclusive of management systems, policies, beliefs and practices. This improved understanding of assessment's nature, role, and impact within higher education systems is increasingly informing the quality assurance practice in developed countries.

Assessment systems should be designed to be mutually supportive in improving the quality of student learning. Student assessment should be regarded as a complex, multidimensional activity that requires alignment, balance and rigour in order to assure quality outcomes. This will certainly enhance the quality of education and in turn the moral values in students' minds. When this happens, it decreases the desire to achieve success through malpractices in examinations. Once such an atmosphere is created, higher education institutions will begin to produce responsible, reliable and honest future citizens who will lead themselves and their country into the realm of development and excellence.

\section{REFERENCES}

ADEA (Association for the Development of Education in Africa). (1999). What works and what's new in education: Africa speaks. Paris.

Ashcroft, K and Rayner, P (2011). "The Purposes and Practices of Quality Assurance in Ethiopian Higher Education: Journey, adaptation and integration". Boersma, FK and Van den Heuvel, H (Eds) (forthcoming) Travelling Ideas in Higher Education Management and Organisation: Prominent developments in Ethiopia, Indonesia and South Africa

Biggs, J. (2003). Teaching for quality learning at university $\left(2^{\text {nd }}\right.$ ed). Berkshire: The Society for Research in Higher Education.

Boud, D. and Falchikov, N. (2006), Aligning assessment with long-term learning", Assessment and Evaluation in Higher Education,31 (4).

Cizek, G.J. (2001). Setting performance standards. Concepts, methods, and perspectives. Mahwah NJ: Lawrence Erlbaum.

Campbell, D. (1976). Assessing the Impact of Planned Social Change. The Public Affairs Center, Dartmouth College, Hanover, $\mathrm{NH}$.

Cizek, G. J. (2004). Cheating in academics. In: Spielberger, C. (Ed.), Encyclopedia of Applied Psychology . San Diego, CA: Academic Press.

Cooper, C. R., and L. Odell. (1977). Evaluating writing: Describing, measuring, judging. Urbana, IL: National Council of Teachers of English. 


\section{Deepika Nelson, Julia Devardhi and Abdulaziz}

Federal Republic of Ethiopia. (2003). Proclamation no 351/2003; Higher Education Proclamation. Federal Republic of Ethiopia: Addis Ababa

Government of Ethiopia. (2003). Higher education proclamation. No. 351/2003. Addis Ababa: Negarit Gazeta.

Harvey (1995). 'Editorial', Quality in Higher Education, $1(1)$.

Higher Education Quality Council, Division of Quality Audit (HEQC DQA) (1993). Notes for Guidance of Auditors, January. Birmingham: HEQC

Huot, B. (1988). The validity of holistic scoring: A comparison of the talk aloud protocols of expert and novice holistic raters. (Doctoral dissertation, Indiana University of Pennsylvania).

Joughin, G. (2010). The hidden curriculum revisited: a critical review of research into the influence of summative assessment on learning. Assessment and Evaluation in Higher Education.

Linn, R.L., Baker, E.L. and Dunbar, S.B. (1991). Complex, performance based assessment: Expectations and validation criteria. Educational Researcher 20(8): 15 -23.

Ministry of Education. (2002). Education Sector Development Program II: 2002/2003 -2004/2005. Federal Republic of Ethiopia: Addis Ababa.

Murdock, T.B. and Anderman, E.M. (2006). Motivational perspectives on student cheating: Toward an integrated model of academic dishonesty. Educational Psychologist, 41

Nitko and Brookhart (2007). Educational Assessment of Students: 5th Edition Pearson Education, Inc., Upper Saddle River, New Jersey.

QAA (UK). (2007). Code of practice for the assurance of academic quality and standards in higher education.Section 6: Assessment of studentsSeptember 2006. Retrieved from http://www.qaa.ac.uk/academicinfrastructure/codeO fPractice/section5/COP_complaints.pdf

Rowntree, D. (1977). Assessing students: How shall we know them? London: Harper and Row.

Senate Legislation of Alemaya University (August 1997), Alemaya university, Ethiopia

Spandel, V. and Stiggens, R.J. (1980). Direct measures of writing skill: Issues and applications. Portland, OR: Northwest Regional Educational Development Laboratory.

McKeachie, W. J. (2002). McKeacthie's teaching tips: Strategies, research, and theory for colleges and university teachers $\left(11^{\text {th }}\right.$ Eds.) Boston: Houghton Mifflin.

Miller, A. Imrie, B., and Cox, K. (1989). Student assessment in higher education: Ahandbook for assessing performance. London: Kogan.
Sci. Technol. Arts Res. J., July-Sep 2012, 1(3): 68-74

Webb, N., and Briars, D. (1990). Assessment in mathematics classrooms, K-8. In T. J. Cooney (ed.), Teaching and Learning Mathematics in the 1990s, 1990 Yearbook of the National Council of Teachers of Mathematics, (Pp. 108-17). Reston, Va:NCTM.

World Bank. (2004). Higher Education Development for Ethiopia: Pursuing the Vision. World Bank: Washington. 